УДК 378.32

\title{
ОБГРУНТУВАННЯ ЗНАЧЕННЯ МЕТОДИКИ “СЕМЕСТРОВОГО ТЕСТОВОГО КОНТРОЛЮ” ДЛЯ ОЦІНКИ ТЕОРЕТИЧНОЇ ТА ПРАКТИЧНОЇ ПІДГОТОВКИ СТУДЕНТІВ-ІНОЗЕМЦІВ У ВИВЧЕННІ ІНОЗЕМНОЇ (УКРАЇНСЬКӦ̈) МОВИ ЗА ПРОФЕСІЙНИМ СПРЯМУВАННЯМ
}

Г. В. Жмудська

ДВНЗ “Тернопільський державниймедичний університет імені І. Я. Горбачевського МОЗ Украӥни”

\section{THE SIGNIFICANCE OF THE "SEMESTER TEST CONTROL" EDUCATIONAL METHODS FOR THE THEORETICAL AND PRACTICAL TRAINING OF FOREIGN STUDENTS IN THE COURSE "PROFESSIONAL FOREIGN LANGUAGE (UKRAINIAN)"}

H.V.Zhmudska

\author{
SHEI “Ternopil State Medical University by I. Ya. Horbachevsky of MPH of Ukraine”
}

\begin{abstract}
У статті обгрунтовується ефективність використання методики "Семестрового тестового контролю" для оцінки теоретичної та практичної підготовки студентів-іноземців у вивченні іноземної (української) мови за професійним спрямуванням.
\end{abstract}

The article discusses the significance of the "Semester test control" educational methods for the theoretical and practical training of foreign students in the course "Professional Foreign (Ukrainian) Language".

Вступ. На сучасному етапі одним з найважливіших напрямків реформування освіти є вдосконалення контролю якості освіти. У той же час традиційна система освіти, що має багатий досвід у галузі контролю результатів навчання, має переважно суб' єктивний характер, і в силу своїх організаційних і технологічних особливостей не може забезпечити об'єктивної інформації про навчальні досягнення студентів. Сьогодні у навчальний процес все ширше впроваджуються письмові тестові завдання. Тестовий контроль знань, як частина існуючих інноваційних навчальних технологій, значною мірою підвищує об'єктивність оцінювання. Це стосується як медичних, так і суспільних та мовних дисциплін.

Серед найбільш вагомих праць, присвячених проблемам впровадження інформаційно-комунікативних технологій у навчальний процес в Україні, можна виділити П. Дмитренка, М. Жалдака, В. Кухаренка, В. Олійника, В. Глушкова, М. Згуровського, В. Михайленка. Проблеми використання інноваційних технологій під час викладання іноземних мов розглядали О. Коваленко, С. Можар, Л. Олійник та інші. Серед науковців, які працювали над проблемою впровадження тестових технологій в освіті і, зокре() Г. В. Жмудська ма, у вивченні іноземних мов, слід назвати О. Кужель, Т. Коваль, Н. А. Алєксєєва.

У Тернопільському державному медичному університеті з 2006-2007 навчального року запроваджені новітні методики оцінювання знань, зокрема: методика щоденного тестового контролю "Moodle" та методика семестрового тестового контролю. У зв’ язку з цим дослідження ефективності тестових технологій контролю знань у вузі є актуальним.

Мета даної статті - обгрунтувати ефективність використання методики семестрового тестового контролю для об' єктивного оцінювання теоретичної та практичної підготовки студентів-іноземців у вивченні іноземної (української) мови за професійним спрямуванням.

Основна частина. Тестування є одним із найсучасніших і науково обгрунтованих методів контролю поточних і підсумкових знань. Цей метод має ряд переваг перед традиційними усними та письмовими іспитами, недоліками яких, в першу чергу, є суб' єктивний та психологічний чинники. Комп'ютерне тестування, під час проведення якого виключається негативний вплив на результати тестування таких факторів, як настрій викладача та рівень його кваліфікації, 
$\epsilon$ найбільш об' єктивною формою оцінювання [2, 3 , 6]. Завдяки технічним можливостям перевірка знань студентів здійснюється об' єктивно і швидко, охоплює весь матеріал навчального курсу, використовує однаковий матеріал і забезпечує однакові умови процедури тестування для кожного студента.

Впродовж 2007-2012 рр. було розроблено комплекс тестових завдань, які направлені на засвоєння знань з навчальних курсів “Іноземна (українська) мова” та “Іноземна (українська) мова за професійним спрямуванням". При розробці комплексу тестових завдань враховувались такі принципи, як валідність, реалістичність, складність, значущість, ефективність та прийнятність [6]. Створена значна за обсягом база тестів, яка постійно поповнюється і вдосконалюється. Після закінчення сесіі, на підставі аналізу складання іспитів навчально-науковим відділом 3 незалежного тестування, тестові завдання проходять перевірку на валідність з корекцією чи заміною невалідних. На сьогодні тестова база з мовних дисциплін для студентів медичного факультету складає 4569 тестів, серед яких 753 тести з рисунками та 767 ситуаційних задач.

Тестові завдання орієнтовані на чітко визначений перелік питань, складений на базі навчальної програми, і містять інформацію про необхідні для студента знання. Зокрема, увага студентів I курсу за передбаченою програмою "Іноземна українська мова" спрямована на вивчення найуживанішої лексики та основ мовного етикету, звертається на засвоєння нової лексики з тем “Моя сім' я”, “Наш університет”, “Магазин”, “Продукти”, “Вулиця”, “Місто”, “Транспорт” ,"Пори року” та інші, що допомагає їм набувати практичних навичок у повсякденному спілкуванні, а підготовка до тестування та позааудиторна робота сприяють досягненню максимального результату у засвоєнні навчального матеріалу.

Для студентів II курсу, що вивчають українську мову за професійним спрямуванням, навчальний матеріал і завдання розроблені та подані таким чином, щоб вони були максимально наближені до реальних ситуацій, які можуть трапитись у їхній професійній діяльності, що значно підвищує мотивацію студентів у підготовці до занять та тестування. Завдяки цьому, у студентів формуються практичні мовні навички, що дозволяє їм впевнено почувати себе у спілкуванні 3 пацієнтами. Одним 3 дієвих факторів стає робота 3 тестовими завданнями як засобами навчання, зокрема у самостійній позааудиторній роботі.

Для допомоги у підготовці до тестування викладачами можуть бути використані додаткові заходи сти- мулювання студентів, зокрема приблизний перелік питань для самостійної підготовки. Це допомагає студентам виявити і усунути прогалини в знаннях, дисциплінує, організовує і спрямовує їх діяльність, формує прагнення розвинути свої здібності [6].

Семестрове тестування в ТДМУ здійснюється подібно до досвіду Віденського медичного університету.

Семестровий тестовий контроль 3 навчальних курсів "Іноземна (українська) мова" та "Іноземна (українська) мова за професійним спрямуванням" включені в семестровий комплексний тестовий іспит, що проводиться після закінчення семестру. На його складання відводиться такий же час, як і для спеціальних медичних дисциплін, тобто одна хвилина на одне тестове завдання, крім того, додаються ще дві хвилини на кожен модуль, що складається з 24 тестових завдань, 4 з яких містять рисунки і 4 - ситуаційні задачі.

Залежно від дисципліни, курсу та факультету у семестровий іспит включаються тести, кількість яких повинна бути кратною 12 і пропорційною до кількості годин, що відводяться на дисципліну. У кожен варіант для семестрового контролю повинно виноситись не менше 24 тестів 3 кожного модуля, які вивчалися у семестрі. Електронні варіанти буклетів тестових завдань створюють напередодні проведення іспиту, комп'ютер в довільному порядку вибирає тести i формує буклет, що безпосередньо виключає можливість зовнішнього впливу на іспит та суб' єктивний чинник [4].

Тестові завдання в одному буклеті відрізняються між собою за змістом та рівнем складності, оскільки рівень знань студентів залежить від індивідуальних здібностей, ставлення до навчання, дисциплінованості студента, що, таким чином, створює рівні умови для всіх студентів.

Студент, який не склав іспиту, має можливість перескласти його ще раз у режимі тестового контролю, при умові отримання повторно незадовільної оцінки іспит складається шляхом співбесіди [4].

Важливо відмітити і організаційно-методичний аспект семестрового тестового іспиту. Адже періодичність і неминучість тестового контролю дисциплінує студентів, організовує їх, заставляючи приділяти увагу підготовці до іспиту. Протягом всього навчального семестру після вивчення кожної теми студенти проходять обов' язковий тестовий контроль, завдяки чому мають можливість ознайомитись 3 приблизним переліком тестових завдань, аналогічних семестровому тестовому іспиту. 
Оскільки екзаменаційний буклет формується із завчасно створеної бази тестів, у ньому представлені тестові завдання, що охоплюють всі розглянуті протягом навчального семестру теми. Таким чином студенти мають можливість засвідчити свій рівень знань та бути всесторонньо та об'єктивно оціненими.

Висновок. Варто відзначити, що усунення людини, як носія суб' єктивності, з процесу контролю позитивно позначається на підвищенні об' єктивності результатів при оцінюванні знань студентів, що складають тестовий іспит. Адже, подолавши прояви

\section{Лiтература}

1. Тестування як основа кредитно-модульного контролю / С. М. Геряк, І. В. Корда, Н. І. Багній [та ін.] // Медична освіта. -2010. - № 1. - С. 77-78.

2. Ковальчук Л. Я. Досвід впровадження семестрового комплексного тестового іспиту в Тернопільському державному медичному університеті імені І. Я. Горбачевського / Л. Я. Ковальчук // Впровадження кредитно-модульної системи організації навчального процесу у ВМ(Ф)НЗ України : результати, проблеми та перспективи : матер. Всеукр. навч.-наук. конф., 20-21 травня 2010 р., м. Тернопіль. - Тернопіль : Укрмедкнига, 2010.- С. 50-59.

3. Семестрові комплексні тестові іспити - надійний критерій оцінки знань студентів / I. Р. Мисула, В. П. Марценюк, К. О. Пашко, О. О. Стаханська//Медична освіта. - 2010. - № 1.-C. 16-37. зовнішнього впливу, зокрема втручання викладача, зробили іспит абсолютно чесним. Це дозволяє оцінювати знання кожного студента максимально об'єктивно та практично усуває можливості корупційних дій за підвищення екзаменаційного бала.

Зрозуміло, що тестування не замінює і не відміняє традиційних форм педагогічного контролю, заснованих на безпосередньому спілкуванні викладача зі студентом. Проте такий контроль виконує важливі навчальні функції, даючи об'єктивну оцінку якості підготовки студента та інформацію про рівень його знань і прогалини при підготовці.

4. Семестровий тестовий контроль рівня знань студентів у Тернопільському та Віденському медичних університетах / I. Р. Мисула, В. П. Марценюк, Г. Я. Загричук, А. Г. Шульгай // Впровадження засад Болонської системи освіти : український і зарубіжний досвід : матер. Всеукр. навч.-наук. конф., 14-15 травня 2007 р., м. Тернопіль. - Тернопіль : Укрмедкнига, 2007.-С. 27-29.

5. Унгурян Л. М. Застосування тестової системи оцінки знань у навчальному процесі / Л. М. Унгурян, М. С. Образенко // Медична освіта. - 2011. - № 3. - С. 20-22.

6. Пашко К. О. Про створення спільної бази тестових завдань для всіх вищих медичних навчальних закладів України / К. О. Пашко, М. О. Кашуба, В. В. Максимова // Медична освіта.-2009. - № 2. - С. 102-104. 